\title{
Demographic Analysis and Intentionality of Injuries in the Emergency Service
}

\author{
Acil Serviste Yaralanmaların Demografik Analizi ve Niyetselliği
}

(D) Mustafa Acin', (D) Halit Karakisa², iD Salim Satar ${ }^{3}$

1- Şanlıurfa Eğitim ve Araştırma Hastanesi, Acil Tıp Kliniği, Şanlıurfa, Turkey. 2- İstanbul Prof. Dr. Cemil Taşçığlu Şehir Hastanesi, Acil Tıp Kliniği, İstanbul, Turkey. 3- Adana Şehir Eğitim ve Araştırma Hastanesi, Acil Tıp Kliniği, Adana, Turkey.

\begin{abstract}
Objectives: In this study, it was aimed to investigate the epidemiological characteristic of the patients admitted to the emergency department as a result of injuries and evaluate the distribution of the injuries according to intentionality (intentional, unintentional) for the first time in Turkey.

Material and Method: All forensic cases over the age of 18 who were admitted due to injuries in two years were analyzed prospectively.

Results: 10.393 (67,39\%) of the cases were male and 5.029 (32.61\%) were female patients. Most of the cases were found to be between the ages of 18-45 $(n=11.128,82.8 \%)$. The most frequent injuries were traffic accidents $(3.407,22,1 \%)$, intoxications $(2.947,19,1 \%)$, falls $(2.279,14,8 \%)$, assaults $(2.202,14,3 \%)$, cutting/stabbing injuries $(2.052,13,3 \%)$. The most common admission to the emergency department were in September $(1.649,10,7 \%)$ and in autumn $(4.499,29,2 \%)$. Intentional injuries constitute $36.1 \%(n=5.555)$ of all injuries, while interpersonal violence accounts for $18.7 \%(n=2.877)$ and self-harm $17.4 \%(n=2.678)$. Unintentional injuries constitute $63.3 \%$ of all injuries, while traffic accidents, falls and cutting/stabbing/ injuries accounts $22.1 \%(n=3.404), 14.7 \%(n=2.262)$, and $8.5 \%(n=1.310)$ respectively. Extremities were the most affected body part ( $n=7.336,53.7 \%$,) due to injuries.

Conclusion: Injuries most commonly affect young adults in the productive age. Intentional injuries account for one-third of all injuries. Assessment of intentionality can be a guide in the determination of the underlying causes and the preventive interventions of injuries.

ÖZET

Amaç: Bu çalışma ile yaralanmalar sonucu acil servise başvuran hastaların epidemiyolojik özelliklerini araşstırmak ve Türkiye'de ilk kez yaralanmaların niyetsellik (kasıtll, kasıtsız) açısından dağıllmı değerlendirmek amaçlandl.

Gereç ve Yöntem: Acil servise iki yıllık sürede yaralanma nedeniyle başvuran 18 yaş üstü tüm adli olgular prospektif olarak analiz edildi.

Bulgular: Olguların 10.393'ü $(\% 67,39)$ erkek ve 5.029'u (\%32.61) kadın hastadan oluşmaktaydl. Olguların büyük çoğunluğunun 18-45 ( $n=11.128, \% 82,8)$ yas aralığında olduğu saptandl. Yaralanmalara en sik trafik kazaları $(3.407, \% 22,1)$, zehirlenmeler $(2.947, \% 19,1)$, düşmeler $(2.279, \% 14,8)$, darplar $(2.202, \% 14,3)$ ve kesici delici alet yaralanmalarl $(2.052, \% 13,3)$ neden olmaktadır. Acil servise en sik eylül ayında (1.649, $\% 10,7)$ ve sonbaharda $(4.499, \% 29,2)$ başvurulmaktadir. Kasitl yaralanmalar tüm yaralanmaların $\% 36,1$ ' 'ini ( $n=5.555)$ oluştururken kişiler arast şiddet bunun \%18,7'sini $(n=2.877)$ ve kendine zarar verme $\% 17,4$ 'ünü $(n=2.678)$ olușturmaktadır. Kasttsız yaralanmalar tüm yaralanmaların \%63,3'ünü olustururken trafik kazalarl, düşmeler ve delici kesici aletle yaralanmalar sirasıyla \%22,1 (n=3.404), \%14,7 (n=2.262) ve \%8,5'ini (n=1.310) olușturmaktadir. Ekstremiteler yaralanmalar sonucu $(7.336, \% 53,7)$ en çok etkilenen vücut bölgeleridir.

Sonuç: Yaralanmalar en çok üretken çağdaki genç erişkinleri etkilemektedir. Kasıtll yaralanmalar tüm yaralanmaların üçte birini oluşturmaktadır. Niyetselliğin değerlendirilmesi yaralanmalarda altta yatan nedenlerin ve önleyici girişimlerin belirlenmesinde yol gösterici olabilir.
\end{abstract}

\section{GíRiş}

Yaralanma insan vücudun fizyolojik tolerans sınırlarını aşan miktarda fiziksel ajanlara (mekanik, termal, elektriksel, kimyasal ya da ışınsal) maaruziyeti sonucu oluşur. Bazı olgularda (boğulma, donma vb.) yaralanma yaşamsal bir ihtiyacın (oksijen, 1sı vb.) yetersizliği sonucu da gelişebilir (1). Yaralanmalar global hastalık yükünün önde gelen nedenlerinden biri olarak dünya genelinde mortalite ve morbiditenin önemli bir sebebidir. Tüm ülkeleri etkilemekle birlikte orta ve düşük gelirli ülkeleri orantısız olarak daha fazla etkilemektedir. Son üç dekatta dünya genelinde
Keywords:

Injuries,

Intentional,

Unintentional

Emergency medicine,

Forensic medicine.

Anahtar Kelimeler:

Yaralanmalar,

Kasitli,

Kasitsiz,

Acil tıp,

Adli tıp.

\section{Received: 18.08 .2020}

popülasyonun 5.27 milyardan 7.39 milyara çıkması sonucunda diğer tüm hastalıklarla birlikte yaralanma sayısı ve bunların sağlık sistemleri üzerindeki ekonomik yükü artmıştır (2).

Dış etkenler sonucunda kişinin sağlığının bozulmasına adli olay, bu olay sonucu oluşan olguya adli olgu denir (3). Adli olguya neden olan etkenler arasinda psikolojik (yoksunluk, sınırlama, bedensel ve sözlü uyaran), fiziksel (termal, elektrik, radyasyon), kimyasal (asit ve alkali korozivler, toksik maddeler), biyolojik (hayvan 1sırıkları ve sokmaları, mikroorganizmalar) ve mekanik dış etkiler (kesici, ezici ve delici cisimler,

Correspondence: Halit Karakısa, Darülaceze Cad. No:27 Şişli, İstanbul, 34384, Turkey. E-mail: halitkarakisa@gmail.com

Cite this article as: Acin M, Karakisa H, Satar S. Demographic Analysis and Intentionality of Injuries in the Emergency Service. Phnx Med J. 2020;2(3):152-159. 
ateşli silahlar ve patlayıcılar) yer almaktadır. Şüpheli ölümler ya da ani ve beklenmedik ölümler de adli olgu kapsamında değerlendirilmektedir. D1ş etkiler kişiyi kasıtlı (kendine zarar verme, kişiler arası şiddet) veya kasıtsız (trafik kazası, düşme, yanık, elektrik çarpması vb.) olarak etkileyebilir. Adli olguların büyük çoğunluğunu oluşturan yaralanmaların ilk başvuru yeri olan acil servisler sundukları sağlık hizmetleri gereği sağlık sistemi ve adalet sistemi arasında özgün bir yerde konumlanmaktadır. Acil servise başvuran olgularda hekimlerin teşhis ve tedavi görevlerinin yanı sıra olayın adli olgu niteliği taşıyıp taşımadığını belirleme, yaralanmaları tanımlama ve yorumlama, adli makamlara olguları bildirme, adli raporları düzenleme, olası delilleri belirleme, toplama ve koruma görevleri yasal olarak zorunlu kılınmıştır. Çok yönlü değerlendirmelerin gerektiği adli olgularda hekim hastanın tıbbi durumunu adalet sistemine bildirerek adaletin tecellisine doğrudan etki etmektedir. $\mathrm{Bu}$ olguların hekimlere yüklediği görevlerin ve sorumlulukların doğal sonucu olarak adli olguların tıbbi kayıtları yaralanmalar açısından en güvenilir ve detaylı verilerdendir.

Yaralanmaların kontrolünde kapsamlı halk sağlığ1 yaklaşımı olarak tanımlanan travma sisteminin gelişmesi yaralanma verilerine ve kesintisiz yaralanma sürveyanına bağlıdır. Veri toplama ve veri analizi yapılmadan travma sisteminde büyük gelişme sağlamak mümkün değildir (4). Prospektif veri toplanması yaralanmaların epidemiyolojisinin önemini vurgulayabilir ve travma sisteminin etkinliğini artırabilir. Standardize edilmiş büyük miktarda veri toplanması hedef popülasyonda yaklaşımların iyileştirilmesini ve geliştirilmesini sağlayabilir, hasta bakım kalitesini ve sonlanımını iyileştirebilir. Yaralanmaların önlenmesi için alınması gereken önlemlerin belirlenmesine ve önceliklendirilmesine, sağlık harcamalarının ve yatırımlarının meşru bir kaideye dayandırılmasına katkı sağlayabilir. Ne yazık ki yaralanmalara bağlı hastalık yükünün \%90'ının meydana geldiği orta ve düşük gelirli ülkelerde travma kayıt sisteminin yürürlüğe konması ve buna uyumun sağlanması oldukça zor olmuştur (4).

Amacimız Türkiye'deki en büyük olgu serilerinden birini oluşturan, yaralanmalar nedeniyle acil servise başvuran adli olguların demografik özelliklerini, yaralanma paternlerini ve niyetsellik açısından dağılımını sunmaktır. Bu verilere katkıda bulunarak acil servislerin yaralanmalar açısından gelişimine katkıda bulunmak, yaralanmaların önlenmesinde odaklanılması gereken noktaların belirlenmesi hedeflendi.

\section{GEREÇ VE YÖNTEM}

$\mathrm{Bu}$ kesitsel prospektif çalışma yaklaşı 2,5 milyon nüfuslu Adana ilinde yer alan, günlük ortalama 1.500 erişkin hastanın acil servise başvurduğu 900 yataklı, zehirlenme merkezi olarak hizmet veren, 3. basamak Adana Numune Eğitim ve Araştırma Hastanesi'nde Girişimsel Olmayan Klinik Araştırmalar Etik Kurulundan 2011/78 karar nosu ile onay alındıktan sonra gerçekleştirildi. Çalışmamıza Adana Numune Hastanesinden etik kurul onayı alındıktan sonra başlandı. Çalışmamız 1964 Helsinki Bildirgesi'nin ve sonraki değişikliklerinin etik standartlarına uygun bir şekilde yürütüldü.

Hastanemiz Acil Tıp Kliniği'ne 01.01.2012-31.12.2013 tarihleri arasında başvuran 18 yaş üstü tüm adli olgular prospektif olarak çalışmaya dahil edildi. Hastaların verileri tetkik ve tedavileri tamamlandiktan sonra olgu kayıt formuna kaydedildi. Hasta yaşı, cinsiyeti, adli olgunun oluş zamanı, nedenleri (trafik kazası, zehirlenme, düşme vb.), kategorisi (kasıtlı, kasıtsız) ve yaralanan vücut bölgesi verileri kaydedildi. Adli olgu nedenlerine ve kategorilerine ait bilgiler hastanın kendisinden, yakınından veya acile getiren ambulans ekibinden elde edildi. Diğer veriler hastane bilgi yönetim sisteminden ve fizik muayene bulgularından elde edildi. Zehirlenme grubuna ilaç zehirlenmeleri, madde alımı, karbonmonoksit zehirlenmesi, mantar zehirlenmeleri, yılan 1sırmas1, akrep sokmas1 ve koroziv madde alımları da dahil edildi. Trafik kazası olgularına bu tanıma uyan bütün olgular dahil edildi.

Tablo-1: Yaralanma nedenlerinin cinsiyetlere göre dağılımı

\begin{tabular}{|c|c|c|c|c|c|c|}
\hline \multirow[b]{2}{*}{ Adli Olgu Nedeni } & \multicolumn{2}{|c|}{ Kadın } & \multicolumn{2}{|c|}{ Erkek } & \multirow[b]{2}{*}{$\mathbf{p}$} & \multirow[b]{2}{*}{ Toplam } \\
\hline & $\mathbf{n}$ & $\%$ & $\mathbf{n}$ & $\%$ & & \\
\hline Trafik Kazası & 954 & 28.00 & 2453 & 72.00 & 0.000 & 3407 \\
\hline Zehirlenmeler & 1734 & 58.84 & 1213 & 41.20 & 0.000 & 2947 \\
\hline Düşme & 755 & 33.13 & 1524 & 66.90 & 0.562 & 2279 \\
\hline Darp & 797 & 36.19 & 1405 & 63.80 & 0.000 & 2202 \\
\hline Kesici Delici Alet Yaralanması & 271 & 13.21 & 1781 & 86.80 & 0.000 & 2052 \\
\hline Yanık & 182 & 49.59 & 185 & 50.40 & 0.000 & 367 \\
\hline Ateşli Silahla Yaralanma & 33 & 17.37 & 157 & 82.60 & 0.000 & 190 \\
\hline Elektrik Çarpması & 35 & 26.12 & 99 & 73.90 & 0.108 & 134 \\
\hline As1 Girişimi & 2 & 11.11 & 16 & 88.90 & 0.052 & 18 \\
\hline Diğerleri & 266 & 14.57 & 1560 & 85.43 & 0.000 & 1826 \\
\hline Toplam & 5029 & 32.61 & 10393 & 67.39 & & 15422 \\
\hline
\end{tabular}


Tablo-2: Yaralanma nedenleri

\begin{tabular}{lcc}
\hline Nedenler & n & \% \\
\hline Trafik Kazası & 3407 & 22.1 \\
Zehirlenmeler & 2947 & 19.1 \\
Düşme & 2279 & 14.8 \\
Darp & 2202 & 14.3 \\
Kesici Delici Aletle Yaralanma & 2052 & 13.3 \\
Yanık & 367 & 2.4 \\
Ateşli Silahla Yaralanma & 190 & 1.2 \\
Elektrik Çarpması & 134 & 0.9 \\
Ası Girişimi & 18 & 0.1 \\
Diğerleri & 1826 & 11.8 \\
\hline Toplam & 15422 & 100 \\
\hline
\end{tabular}

Düşme olguları tüm seviyelerden düşmeleri kapsamaktadır. Çalışmamız süresince toplam 15.422 hastanın verileri toplandı. Verilerin eksik kaydedilmesi ya da detaylı bilgi alınamaması nedeniyle 1.826 hastanın verilerine tam olarak ulaşılamadı. Elde edilen veriler istatistiksel olarak SPSS 22.0 paket programı kullanılarak analiz edildi. Verilerin tanımlayıcı istatistiklerinde oran değerleri kullanılmıştır. Niteliksel verilerin analizinde ki-kare test, test koşulları sağlanmadığında Fischer Test kullanıldı. İstatistiksel olarak p $<0.05$ değeri anlamlı kabul edildi.

\section{BULGULAR}

Çalışmaya toplam 15.422 hasta dahil edildi. Hastaların 10.393’ü (\%67.39) erkek ve 5.029'u (\%32.61) kadındı. Erkek cinsiyette genel dağılıma kıyasla trafik kazası, darp, kesici delici aletle yaralanma ve ateşli silah yaralanmasının, kadınlarda ise yanık ve zehirlenmelerin istatistiksel olarak anlamlı derecede daha fazla olduğu bulundu (Tablo-1).

Yaralanmalara en sık trafik kazalarının (3.407, \%22.1) sebep olduğu belirlendi. Diğer nedenler sıklık sırasıyla; zehirlenmeler (2.947, \%19.1), düşme (2.279, \%14.8), darp (2.202, \%14.3), kesici delici alet yaralanması (2.052, \%13.3), yanık (367, \%2.4), ateşli silah yaralanması (190, \%1.2), elektrik çarpması (134, $\% 0.9$ ), as1 girişimi $(18, \% 0.1)$ ve diğerleri (bilgi alınamayan, verileri kaydedilmeyen, cinsel saldırı, şüpheli ölüm, suda boğulma), (1.826, \%11.8) idi (Tablo-2).

Hastaların büyük çoğunluğunun 18-45 (n= 11.128, \%82.8) yaş aralığında olduğu belirlendi. Tüm hastaların \%15'ini $(\mathrm{n}=2.034)$ 46-65 yaş arası, \%3.2'sini $(n=434)$ ise 65 yaş üstü hastalar ise oluşturmuştur (Tablo-3). Yaralanmaların en sik 18-25 yaş arası bireylerde meydana geldiği saptandı.

Olguların en sık eylül ayında (1.649 olgu, \%10.7) ve sonbaharda (4.499 olgu, \%29.2) acile başvurduğu tespit edildi. Trafik kazası, düşme, kesici delici aletle

Tablo-3: Yaralanma nedenlerinin yaş gruplarına göre dağılımı

\begin{tabular}{|c|c|c|c|c|c|c|c|c|c|c|}
\hline \multirow[b]{2}{*}{ Yaralanma Nedeni } & & \multicolumn{8}{|c|}{ Yaş Grupları } & \multirow[b]{2}{*}{ Toplam } \\
\hline & & $18-25$ & $26-35$ & $36-45$ & $46-55$ & $56-65$ & $66-75$ & $76-85$ & 86-104 & \\
\hline \multirow{2}{*}{ Trafik Kazası } & $\mathrm{n}$ & 1109 & 986 & 588 & 372 & 226 & 78 & 41 & 7 & \multirow{2}{*}{3407} \\
\hline & $\%$ & 32.6 & 28.9 & 17.3 & 10.9 & 6.6 & 2.3 & 1.2 & 0.2 & \\
\hline \multirow{2}{*}{ Zehirlenme } & $\mathrm{n}$ & 1226 & 956 & 437 & 200 & 87 & 22 & 16 & 3 & \multirow{2}{*}{2947} \\
\hline & $\%$ & 41.6 & 32.4 & 14.8 & 6.8 & 3.0 & 0.7 & 0.5 & 0.1 & \\
\hline \multirow{2}{*}{ Düşme } & $\mathrm{n}$ & 620 & 613 & 394 & 291 & 179 & 95 & 68 & 19 & \multirow[t]{2}{*}{2279} \\
\hline & $\%$ & 27.1 & 26.9 & 17.3 & 12.8 & 7.9 & 4.2 & 3.0 & 0.8 & \\
\hline \multirow{2}{*}{ Darp } & $\mathrm{n}$ & 667 & 736 & 424 & 231 & 98 & 30 & 13 & 3 & \multirow[t]{2}{*}{2202} \\
\hline & $\%$ & 30.3 & 33.4 & 19.3 & 10.5 & 4.5 & 1.4 & 0.6 & 0.1 & \\
\hline \multirow{2}{*}{ Kesici Delici Aletle Yaralanma } & $\mathrm{n}$ & 747 & 687 & 353 & 163 & 77 & 17 & 8 & 0 & \multirow[t]{2}{*}{2052} \\
\hline & $\%$ & 36.4 & 33.5 & 17.2 & 7.9 & 3.8 & 0.8 & 0.4 & 0.0 & \\
\hline \multirow{2}{*}{ Yanık } & $\mathrm{n}$ & 106 & 119 & 71 & 42 & 19 & 6 & 4 & 0 & \multirow[t]{2}{*}{367} \\
\hline & $\%$ & 28.7 & 32.5 & 19.4 & 11.5 & 5.2 & 1.6 & 1.1 & 0.0 & \\
\hline \multirow{2}{*}{ Ateşli Silahla Yaralanma } & $\mathrm{n}$ & 77 & 54 & 22 & 21 & 12 & 3 & 1 & 0 & \multirow{2}{*}{190} \\
\hline & $\%$ & 40.5 & 28.4 & 11.6 & 11.1 & 6.3 & 1.6 & 0.5 & 0.0 & \\
\hline \multirow{2}{*}{ Elektrik Çarpması } & $\mathrm{n}$ & 32 & 59 & 27 & 13 & 3 & 0 & 0 & 0 & \multirow[t]{2}{*}{134} \\
\hline & $\%$ & 23.9 & 44.0 & 20.1 & 9.7 & 2.2 & 0.0 & 0.0 & 0.0 & \\
\hline \multirow{2}{*}{ Ası Girişimi } & $\mathrm{n}$ & 6 & 7 & 5 & 0 & 0 & 0 & 0 & 0 & \multirow[t]{2}{*}{18} \\
\hline & $\%$ & 33.3 & 38.9 & 27.8 & 0.0 & 0.0 & 0.0 & 0.0 & 0.0 & \\
\hline \multirow[t]{2}{*}{ Toplam } & $\mathrm{n}$ & 4590 & 4217 & 2321 & 1333 & 701 & 251 & 151 & 32 & 13596 \\
\hline & $\%$ & 33.8 & 31.0 & 17.1 & 9.8 & 5.2 & 1.8 & 1.1 & 0.2 & 100 \\
\hline
\end{tabular}


Tablo-4: Yaralanmaların aylara göre dağılımı

\begin{tabular}{lcc}
\hline Aylar & $\mathbf{n}$ & $\mathbf{\%}$ \\
\hline Ocak & 937 & 6.1 \\
Şubat & 1004 & 6.5 \\
Mart & 1103 & 7.2 \\
Nisan & 995 & 6.5 \\
Mayıs & 1249 & 8.1 \\
Haziran & 1404 & 9.1 \\
Temmuz & 1405 & 9.1 \\
A ğustos & 1464 & 9.5 \\
Eylül & 1649 & 10.7 \\
Ekim & 1446 & 9.4 \\
Kasim & 1404 & 9.1 \\
Aralık & 1362 & 8.8 \\
\hline
\end{tabular}

yaralanma, yanık, ateşli silah yaralanması olguları sonbaharda daha sik iken, zehirlenme, darp, elektrik çarpması ve ası girişimi olguları yaz mevsiminde daha s1k idi (Tablo-5). Adli olguların mevsimlere ve aylara göre dağllımı Tablo-4'te ve Tablo-5'te gösterildi.

Yaralanmalar oluş mekanizmasına göre kasıtlı ya da kasıtsız olmak üzere iki gruba ayrıldı. Kasıtlı yaralanmalar ise kişiler arası şiddet ve kendine zarar verme olmak üzere iki gruba ayrıldı. Kasıtlı yaralanmalar tüm yaralanmaların \%36.1'ini oluşturmaktadır. Kişiler arası şiddet tüm yaralanmaların \%18.7'sini $(n=2.877)$ oluştururken bu durum en s1k darp (\%14.3, n=2.202), kesici delici aletle yaralanma $(\% 3.2, n=498)$ ve ateşli silahla yaralanma $(\% 1, n=160)$ yoluyla gelişmektedir. Kendine zarar verme tüm yaralanmaların \%17.4'ünü $(n=2.678)$ oluştururken en sik zehirlenme (\%12.7, $n=1.966)$, madde alımı (\%2.7, $\mathrm{n}=419)$ ve kesici delici aletle yaralanma $(\% 1.6, \mathrm{n}=244)$ yoluyla gelişmektedir.
\%22.1 (n=3.404), \%14.7 $\quad(n=2.262) \quad$ ve \%8.5'ini $(n=1.310)$ oluşturarak bu durumun en sik nedenleri arasında yer almaktadirlar (Tablo-6).

Çalışmaya dahil edilen olguların 10.601'inde (\%68.7) travmaya bağlı gelişen bulgulara rastlandı. $\mathrm{Bu}$ olgularda yaralanan vücut bölgeleri açısından en s1k ekstremiteler (7.336, \%53.7), baş-boyun bölgesi (4.276 olgu, \%31.3), batın (1.265 olgu, \%9.3), göğüs (673 olgu, \%4.9) ve vertebra (106, \%0.8) olduğu saptand. Ekstremite yaralanmalarına en sik neden olan yaralanma nedenleri sırasıyla trafik kazası, kesici delici aletle yaralanma, düşme ve darptır. Baş boyun yaralanmalarına en sik neden olanlar ise darp, trafik kazası ve düşmedir (Tablo-7).

Tüm hastaların 13.818'i (\%89.6) acil servisten taburcu edildi, 1.576's1 (\%10.2) yatırılarak tedavi edildi ve 28’si (\%0.2) hastane öncesi veya acil serviste öldü.

\section{TARTIŞMA}

Yaralanmalar genellikle altta yatan niyet esas alınarak kasitlı ve kasitsız olarak kategorize edilir. Yaralanmalarda böyle bir ayrım yapılmasındaki amaç altta yatan ya da katkıda bulunan farklı faktörlerin vurgulanmasına öncülük edebilir ve önleyici girişimlerin geliştirilmesinde kullanışlı olabilir (5). Bu kategorizasyonun kıyaslandığı bir çalışmada kasıtlı düşme nedeniyle acile başvuran hastalarda mortalite oranı kasıtsız olanlara göre daha yüksek bulunmuştur (6). Mortalite oranı kasıtlı ateşli silah yaralanmalarında ve asılarda daha yüksek iken kasitsız zehirlenmelerde en düşük oranda saptandı (7). Han ve ark. yaptığı çalışmada ise kasıtlı düşmelerle kasıtsızlar arasında yaş, yükseklik, vital bulgular, travma skorları, alkol kullanımı ve istihdam ile ilişkili farklılıklar saptanmıştır. Bütün bunlara ilaveten kasıtlı düşmelerde

Tablo-5: Yaralanmaların mevsimlere göre dağılımı

\begin{tabular}{|c|c|c|c|c|c|c|c|c|c|}
\hline & \multicolumn{8}{|c|}{ Mevsimler } & \multirow[b]{3}{*}{ Toplam } \\
\hline & \multicolumn{2}{|c|}{ KIş } & \multicolumn{2}{|c|}{ İlkbahar } & \multicolumn{2}{|c|}{ Yaz } & \multicolumn{2}{|c|}{ Sonbahar } & \\
\hline & $\mathbf{n}$ & $\%$ & $\mathbf{n}$ & $\%$ & $\mathbf{n}$ & $\%$ & $\mathbf{n}$ & $\%$ & \\
\hline Trafik Kazası & 695 & $20.40 \%$ & 787 & $23.10 \%$ & 927 & $27.20 \%$ & 998 & $29.30 \%$ & 3407 \\
\hline Zehirlenme & 705 & $23.90 \%$ & 709 & $24.10 \%$ & 837 & $28.40 \%$ & 696 & $23.60 \%$ & 2947 \\
\hline Düşme & 499 & $21.90 \%$ & 438 & $19.20 \%$ & 563 & $24.70 \%$ & 779 & $34.20 \%$ & 2279 \\
\hline Darp & 425 & $19.30 \%$ & 485 & $22.00 \%$ & 701 & $31.80 \%$ & 591 & $26.80 \%$ & 2202 \\
\hline Kesici Delici Aletle Yaralanma & 430 & $21.00 \%$ & 385 & $18.80 \%$ & 565 & $27.50 \%$ & 672 & $32.70 \%$ & 2052 \\
\hline Yanık & 111 & $30.20 \%$ & 60 & $16.30 \%$ & 72 & $19.60 \%$ & 124 & $33.80 \%$ & 367 \\
\hline Ateşli Silahla Yaralanma & 34 & $17.90 \%$ & 39 & $20.50 \%$ & 51 & $26.80 \%$ & 66 & $34.70 \%$ & 190 \\
\hline Elektrik Çarpması & 16 & $11.90 \%$ & 27 & $20.10 \%$ & 48 & $35.80 \%$ & 43 & $32.10 \%$ & 134 \\
\hline Ası Girişimi & 4 & $16.70 \%$ & 5 & $27.80 \%$ & 5 & $33.30 \%$ & 4 & $22.20 \%$ & 18 \\
\hline Toplam & 2919 & 21.5 & 2935 & 21.6 & 3769 & 27.7 & 3973 & 29.2 & 13596 \\
\hline
\end{tabular}

Kasıtsız yaralanmalar tüm yaralanmaların \%63.3’ünü oluşturmaktadır. Trafik kazaları, düşmeler ve delici kesici aletle yaralanmaları sırasıyla tüm yaralanmaların intihar girişimin yüksek oranda saptanması ve genç popülasyonda 4 metre ve üstü yüksekten düşmelerin daha sık görülmesi daha fazla önlem ihtiyacına işaret 
Tablo-6: Yaralanma kategorileri

\begin{tabular}{|c|c|c|}
\hline \multicolumn{3}{|l|}{ KASITLI YARALANMALAR } \\
\hline Kişiler Arası Şiddet & n & $\%$ \\
\hline Darp & 2202 & 14.3 \\
\hline \multicolumn{3}{|l|}{ Kesici Delici Aletle } \\
\hline Yaralanma & 498 & 3.2 \\
\hline Ateșli Silahla Yaralanma & 160 & 1.0 \\
\hline Zehirlenme & 10 & 0.1 \\
\hline Düşme & 1 & 0.0 \\
\hline Diğerleri & 6 & 0.0 \\
\hline Toplam & 2877 & 18.7 \\
\hline \multicolumn{3}{|l|}{ Kendine Zarar Verme } \\
\hline Zehirlenme & 1966 & 12.7 \\
\hline \multicolumn{3}{|l|}{ Kesici Delici Aletle } \\
\hline Yaralanma & 244 & 1.6 \\
\hline Düşme & 16 & 0.1 \\
\hline Ası Girişimi & 18 & 0.1 \\
\hline Trafik Kazası & 3 & 0.0 \\
\hline Ateşli Silahla Yaralanma & 1 & 0.0 \\
\hline Yanık & 2 & 0.0 \\
\hline Madde Alımı & 419 & 2.7 \\
\hline Diğerleri & 9 & 0.1 \\
\hline Toplam & 2678 & 17.4 \\
\hline \multicolumn{3}{|l|}{ KASITSIZ YARALANMALAR } \\
\hline Trafik Kazası & 3404 & 22.1 \\
\hline Düșme & 2262 & 14.7 \\
\hline \multicolumn{3}{|l|}{ Kesici Delici Aletle } \\
\hline Yaralanma & 1310 & 8.5 \\
\hline Zehirlenme & 552 & 3.6 \\
\hline Yanık & 365 & 2.4 \\
\hline Elektrik Çarpması & 134 & 0.9 \\
\hline Ateşli Silahla Yaralanma & 29 & 0.2 \\
\hline Diğgerleri & 1706 & 11.0 \\
\hline Toplam & 9762 & 63.3 \\
\hline DİĞERLERİ & 105 & 0.7 \\
\hline Genel Toplam & 15422 & 100 \\
\hline
\end{tabular}

etmektedir (8). Genel olarak kasitlı yaralanmalarda davranışı etkileyen ırk, cinsiyet, ekonomik disparite, coğrafik lokasyon ve cinsel eğilim araştırmaların odak noktasını oluştururken kasıtsız yaralanmalarda nesnelerin ya da çevrenin insan ile etkileşimi değerlendirilmektedir. Kasıtlı yaralanma konuları ve stratejileri toplum odaklı, duygusal, siyasi olarak yönetilen şeklinde tanımlanırken kasıtsız yaralanmalar daha tarafsız, dizayn odaklı, ihtilafsız olarak tanımlanmaktadır (5).

Çalışmamızda yaralanmaların en sık üretkenlik çağındaki genç erişkinleri etkilediği gösterilmiştir. $\mathrm{Bu}$ açıdan değerlendirildiğinde bulgularımız literatür ile uyumludur (9-12). Ülkemizin dinamik ve genç nüfus yapısı göz önüne alındığında yaralanmaların giderek artması tahmininde bulunulabilir.

Verilerimiz daha önceki çalışmalarda saptandığı gibi yaralanmalardaki erkek baskınlığını teyit etmektedir $(10,11)$. Erkekler trafik kazasına, darba, kesici delici aletle yaralanmaya ve ateşli silah yaralanmasına daha fazla maruz kalırken kadınlar zehirlenmeye ve yanığa daha fazla maruz kalmaktadır. Erkeklerde yaralanmaların daha fazla görülmesi sosyal yaşamda daha fazla yer almalarına, tehlikeli işlerde daha fazla istihdam edilmelerine ve risk alma eğilimlerinin daha fazla olmasına bağlanmaktadır. Zehirlenmelerin kadınlarda daha sık görülmesi psikolojik hastalıkların genç kadınlarda daha sık görülmesine, psikolojik strese daha fazla maruz kalmalarına ve zehirlenmeyi bir dikkat çekme veya kurtuluş yöntemi olarak görmelerine bağlanmaktadır (13). Toplumumuzda ev kazalarına kadınların daha fazla maruz kalması yanıkların kadınlarda daha sık görülmesini açıklayabilir.

Yaralanmalar nedeniyle acil servislere başvuran hasta sayısı aylara ve mevsimlere göre farklılık göstermektedir. Hava şartları yaralanmaların insidansını birçok şekilde etkileyebilir. Yaralanmalara bağlı başvuru sayısı ile belirgin olarak korele olan meteorolojik faktörler arasında maksimum sicaklık, rüzgar hızı ve yönü, güneşlenme süresi, hava basıncı ve nemlilik yer almaktadır (14). Çalışmamızın yapıldığ hastanemizle aynı Akdeniz iklimine sahip olan İsrail'de yapılan çalışmada da bizim sonuçlarımızla uyumlu olarak yaz ve sonbahar aylarında başvuru oranları yüksek iken aralık ve nisan ayları arasında en az başvurunun olduğu saptanmıştır (15).

Yaralanma nedenleri arasında en sık trafik kazaları, zehirlenmeler, düşmeler, darp ve kesici delici alet yaralanmaları yer almaktadır. Nedenlerin sıklık sıralaması zehirlenmeler hariç benzer olsa da dağılım oranları farklılık göstermektedir $(10,11,16)$. Bu oransal farklılıklara dahil edilen hasta grubu, çalışmaların yapıldığı ülke ve merkezlerin şehirde ya da kırsal bölgede yerleşimi, travma ya da zehirlenme merkezi olarak çalışması ve üniversite ya da devlet hastanesi olması neden olabilir.

Çalışmamızın sonuçları kasıtlı yaralanmaların, kişiler arası şiddet ve kendine zarar verme, tüm yaralanmaların üçte birlik kısmını oluşturduğunu göstermektedir. Aynı zamanda geriye kalan büyük çoğunluğuna ise transport ve transport dişı kasitsız yaralanmaların neden olduğunu göstermektedir. Zehirlenme hastalarının sayıca çok olmasından dolayı kendi kendine zarar verme yaralanmalarının oranı yüksek saptansa da diğer yaralanma nedenlerinin dağılımı literatür ile uyumludur $(7,17,18)$. Bizim bilgilerimize göre ülkemizde yaralanmalar konusunda niyetsellliğin genel dağılımının değerlendirildiği bir çalışmaya rastlayamadık. Ancak düşmeler (6), zehirlenmeler (13), üzerine yapılan çalışmalarla niyetsellik açısından sonuçlar benzerdi. Yaralanmalarda altta yatan nedenlerin ortaya çıkarılması ve kişileri buna yönelten motivasyonların belirlenmesi alınacak önleyici tedbirlerin kalitesini ve girişimlerin başarı oranını arttırabilir.

IRTAD (Uluslararası Trafik Güvenliği Veri ve Analiz Grubu) 1992 Viyana Toplantısına göre yol kullanıcısının (insan veya hayvan) yaralanması ile sonuçlanan umumi yolda hareket eden taşıtın çarpma/çarpışması kasıtsı yaralanma nedenleri arasında yer alan trafik kazasının standart uluslararası tanımını ifade etmektedir. Türkiye'de 2002 yılından 2018 yılına kadar trafikteki taşıt sayısı, maddi hasarlı kaza sayısı, ölümlü-yaralanmalı kaza sayısı ve yaralı sayısı yaklaşık 3 kat artmıştır (19). 2002-2018 yılları arasında ölümlerin ve yaralanmaların yaş gruplarına 
Tablo-7: Yaralanan vücut bölgelerinin nedenlere göre dağılımı

\begin{tabular}{|c|c|c|c|c|c|c|c|c|}
\hline & \multirow{2}{*}{\multicolumn{2}{|c|}{ Yaralanma Sayısı/Oranı }} & \multicolumn{6}{|c|}{ Yaralanma Bölgesi } \\
\hline & & & Baş/Boyun & Batın & Ekstremite & Toraks & Vertebra & Toplam \\
\hline \multirow[t]{2}{*}{ Trafik Kazası } & $\mathrm{n}$ & 3407 & 1399 & 494 & 2480 & 295 & 55 & 4723 \\
\hline & $\%$ & 100.0 & 41.1 & 14.5 & 72.8 & 8.7 & 1.6 & 34.6 \\
\hline \multirow[t]{2}{*}{ Düşme } & $\mathrm{n}$ & 2274 & 993 & 282 & 1493 & 116 & 46 & 2930 \\
\hline & $\%$ & 99.8 & 43.6 & 12.4 & 65.5 & 5.1 & 2.0 & 21.5 \\
\hline \multirow[t]{2}{*}{ Darp } & $\mathrm{n}$ & 2202 & 1552 & 216 & 1077 & 206 & 2 & 3053 \\
\hline & $\%$ & 100.0 & 70.5 & 9.8 & 48.9 & 9.4 & 0.1 & 22.4 \\
\hline \multirow{2}{*}{$\begin{array}{l}\text { Kesici Delici Aletle } \\
\text { Yaralanma }\end{array}$} & $\mathrm{n}$ & 2051 & 163 & 168 & 1749 & 17 & 0 & 2097 \\
\hline & $\%$ & 100.0 & 7.9 & 8.2 & 85.2 & 0.8 & 0.0 & 15.4 \\
\hline \multirow[t]{2}{*}{ Yanık } & $\mathrm{n}$ & 367 & 98 & 26 & 311 & 20 & 0 & 455 \\
\hline & $\%$ & 100.0 & 26.6 & 7.1 & 84.8 & 5.4 & 0.0 & 3.3 \\
\hline \multirow{2}{*}{$\begin{array}{l}\text { Ateşli Silahla } \\
\text { Yaralanma }\end{array}$} & $\mathrm{n}$ & 190 & 36 & 54 & 145 & 11 & 1 & 247 \\
\hline & $\%$ & 100.0 & 18.7 & 28.3 & 76.3 & 5.9 & 0.5 & 1.8 \\
\hline \multirow[t]{2}{*}{ Elektrik Çarpması } & $\mathrm{n}$ & 60 & 12 & 9 & 54 & 6 & 1 & 82 \\
\hline & $\%$ & 44.8 & 9.1 & 6.5 & 40.3 & 4.5 & 0.6 & 0.6 \\
\hline \multirow[t]{2}{*}{ Zehirlenme } & $\mathrm{n}$ & 34 & 8 & 16 & 26 & 2 & 0 & 52 \\
\hline & $\%$ & 1.2 & 0.3 & 0.5 & 0.9 & 0.1 & 0.0 & 0.4 \\
\hline \multirow[t]{2}{*}{ Ası Girişimimi } & $\mathrm{n}$ & 16 & 15 & 0 & 1 & 0 & 1 & 17 \\
\hline & $\%$ & 88.9 & 83.3 & 0.0 & 5.6 & 0.0 & 5.6 & 0.1 \\
\hline \multirow[t]{2}{*}{ Toplam } & $\mathbf{n}$ & 10601 & 4276 & 1265 & 7336 & 673 & 106 & 13656 \\
\hline & $\%$ & 68.7 & 31.3 & 9.3 & 53.7 & 4.9 & 0.8 & 100 \\
\hline
\end{tabular}

göre dağılımı ise değişmeden en çok 25-64 yaş grubunu sonrasında 18-25 yaş grubunu etkilemiştir (20). Sonuçlarımız küresel ve bölgesel verilere uygun bir şekilde ekonomik olarak en üretken yaş grubunda yer alan erkekler trafik kazalarına bağlı yaralanmaların büyük çoğunluğunu oluşturmaktadır (20-22). Erkek olmak ve maskülen cinsiyet rolüne sahip olmak genç erkekleri riskli araç kullanmaya, trafik kazalarına, kural ihlallerine daha yatkın hale getirmektedir (23). Yaralanan vücut bölgeleri açısından sonuçlar kıyaslandığında birbirine oldukça yakındır (24). Ekonomik olarak büyüyen ve gelişen, nüfus sayısı giderek artan ülkemizde önleyici girişimler arttırılmadığı takdirde trafik kazalarına bağlı ekonomik zararların ve hastalık yükünün ağırlığını daha da fazla hissettirmesi ve acil sağlık hizmetlerinin bu olgularla daha fazla meşguliyeti tahmin edilebilir.

Düşme, bir kişin istemsiz bir şekilde yerde, zeminde ya da düşük bir seviyede durması ile sonuçlanan olay olarak tanımlanır. Çalışmamızda düşmelerin trafik kazalarından sonra kasıtsız yaralanmaların ikinci önde gelen nedenini oluşturması literatür ile uyumludur (25). Türkiye'de yapılan çalışmalarda düşmeler \%2.63 ile \%36.8 arasında yaralanmaların nedenini oluşturmaktadır $(11,10)$. Yaş, düşme yüksekliği ve yeri, kafa ya da vertebra yaralanması ve travma skorları düşme nedeniyle gelen hastalarda mortalite ile ilişkili bulunmuştur (6). Niyetsellik, cinsiyet, mevsim ve yaş gruplarına göre dağılımları ise benzerdir $(6,10)$.

Kasıtlı yaralanmalar içerisinde yer alan şiddet; fiziksel kuvvetin ya da gücün, birisine ya da topluluğa karş1 yaralanmaya, ölüme, psikolojik zarara, gelişim bozukluğuna ya da mahrumiyete neden olacak ya da olma ihtimali yüksek bir şekilde, tehditsel ya da eylemsel olarak istemli bir şekilde kullanılması olarak tanımlanır Şiddet her yıl 1.3 milyon kişinin ölümüne neden olmasıyla ve 15-44 yaş arası insanlarda ölümlerin 4. sık nedenini oluşturmasıyla birlikte her gün on binlerce insan ölümcül olmayan şiddete, bunlar arasında acil serviste tedavi gerektiren fiziksel yaralanmalara neden olan saldirılar, cinsel ve psikolojik istismar yer almakta, maruz kalmaktadır (26). Çalışmamızdaki kişiler arası şiddet olgularında erkek baskınlığı ve çoğunlukla genç erişkinlerde görülmesi diğer çalışmalarla uyumludur (4,27). Ekonomik adaletsizlikle ilişkili faktörlerin sağlıklı sosyal gelişimi engelleyerek genç erkeklerde şiddete katkıda bulunduğu gösterilmiştir (28). Kişiler arası şiddet nedenlerinin dağılımı GBD (Global Hastalık Yükü) 2017 tahminleri ile uyumludur (17). Nedenlerin dağılımında ateşli silah yaralanmasının çalışmamızda daha az görülmesinin nedeni ülkemizde uygulanan kanunlara bağlı bireysel silahlanmanın görece düşük olmasına bağlı olabilir. Darp olgularının daha sık görülmesinin nedeni toplumumuzda kişiler arası anlaşmazlıklarda şiddettin daha çok tehdit amaçlı veya güç üstünlüğünü gösterme amacıyla kullanılmasından kaynaklanabilir. Özellikle darbın kişiler arası şiddette yüksek oranda yer alması nedeniyle bunlara yönelik hukuki cezaların arttırılması önleyici girişimler arasında düşünülebilir.

Kendine zarar verme yaralanmalarında zehirlenmeler ve delici kesici aletle yaralanmaları büyük çoğunluğu oluşturmaktadır. Zehirlenmelerin büyük oranda kasıtlı olarak meydana gelmesi, genç kadınları etkilemesi, yaz mevsiminde daha sık görülmesi önceki çalışmalarla uyumludur $(29,30)$. Genç kadın baskınlığına sebep psikolojik ve sosyal baskılara daha fazla maruz kalmaları, zehirlenmeleri bir nevi kurtuluş ya da kendini ifade etme yöntemi olarak kullanmaları öne sürülmektedir $(13,30)$. Büyük çoğunluğunun kasitlı meydana gelmesi nedeniyle birey odakl, intihar dürtüsünün altta yatan nedenlerini aydınlatıcı çalışmalara ihtiyaç vardır.

Yaralanmaların diğer nedenleri arasında yer alan delici kesici aletle yaralanmalar, elektrik çarpması, yanık, ası 
girişimi, cinsel istismar ve şüpheli ölümler de önemli halk sağlığı problemi olmaya devam etmektedirler. Önleyici girişimler bu nedenlerin verdiği zararın azaltılmasında önemini korumaktadır.

Ölen ya da majör travmalı hastalarda en sık etkilenen vücut bölgesi baş boyun bölgesidir. Bütün travma hastalarının birlikte değerlendirildiği birçok çalışmada ise yaralanmalara bağlı en sık etkilenen vücut bölgeleri sırasıyla ekstremiteler, baş boyun bölgesi, toraks ve abdomendir $(11,16,18,31)$. $\mathrm{Bu}$ açıdan verilerimiz literatür ile uyumludur.

Çalışmamızın birçok limitasyonu vardır. Verilerimiz sadece başvuru bilgilerini içermesi demografik analizlere izin vermektedir. Ancak her bir travma nedeninin ayrı ayrı incelenmesinin, risk faktörlerinin ve mortaliteye katkıda bulunan faktörlerin değerlendirilmesinin ve niyetsellliğin yaralanma nedenlerinin üzerine etkisinin değerlendirilmesinin yaralanmaları önlemede ve bunlara bağlı mortalitenin ve morbiditenin azaltılmasına katkı sağlayacağına inanıyoruz. Yaralanmalar sonrası adli veya hukuki süreçlerin başlatılabileceğinin bilinmesi bilgi kaynağ 1 kişilerin çalışmaya katılmama ya da gerçeklerden farklı beyanda bulunma yönünde bask1 oluşturabilir. Diğer limitasyonlar arasında tek merkezli olması ve zehirlenme merkezinde yapılması, sadece adli olguların verilerinin çalışmaya dahil edilmesi, hekimlerin çalışmaya uyumunun ve katkısının düzeyinin bilinmemesi yer almaktadır.

Sonuç olarak; kasıtlı yaralanmalar tüm yaralanmaların üçte birini oluşturmaktadır. Trafik kazaları, kişiler arası şiddet ve zehirlenmeler önde gelen yaralanma nedenleridir. Yaralanmalar halen üretkenlik çağındaki genç nüfusu etkilemeye devam etmektedir. Ülkemizin gelişimi ve artan nüfusu göz önüne alındığında ve gerekli önlemler alınmadığında sağlık hizmetlerinin yaralanma hastalarına daha fazla hizmet vereceği öngörülebilecek bir sonuçtur.

\section{Çıkar İlișkisi}

Tüm yazarlar çıkar çatışması olmadığını beyan eder.

\section{KAYNAKLAR}

1. Norton R, and Olive K. Injuries. New Engl J Med. 2013;368(18): 1723-1730.

2. Hay SI, Abajobir AA, Abate KH, Abbafati C, Abbas KM, Abd-Allah F, et al. Global, regional, and national disability-adjusted life-years (DALYs) for 333 diseases and injuries and healthy life expectancy (HALE) for 195 . countries and territories, 1990-2016: a systematic analysis for the Global Burden of Disease Study 2016. Lancet. 2017;390(10100): 1260-1344.

3. Fincancı KŞ. Adli olguya yaklaşım. İ.Ü. Cerrahpaşa Tıp Fakültesi Sürekli Tıp Eğitimi Etkinlikleri Yeni Yasalar Çerçevesinde Hekimlerin Hukuki ve Cezai Sorumluluğu, T1bbi Malpraktis ve Adli Raporlar`n Düzenlenmesi Sempozyum Dizisi . 2006, İstanbul, Cilt 48, s. $92-103$.

4. Nicol A, Knowlton LM, Schuurman N, Matzopoulos R, Zargaran E, Cinnamon J, et al. Trauma surveillance in Cape Town, South Africa: an analysis of 9236 consecutive trauma center admissions. Jama Surg. 2014;149(6): 549-556.

5. Cohen L, Miller T, Sheppard MA, Gordon E, Gantz T, Atnafou R. Bridging the gap: bringing together intentional and unintentional injury prevention efforts to improve health and well being. J Safety Res. 2003;34(5): 473-483.

6. Turgut K, Sariha, ME, Colak C, Güven T, Gür A, Gürbüz S. Falls from height: A retrospective analysis. World J Emerg Med. 2018;9(1): 46.

7. Gawryszewski VP, Rodrigues EMS. The burden of injury in Brazil, 2003. Sao Paulo Med J. 2006;124(4): 208-213.

8. Han SU, Kim SP, Kim SH, Cho GC, Kim MJ, Lee JS, et al. Gender and Intentionality disparities in the Epidemiology and outcomes of falls from Height in Korean adults. J Trauma Inj. 2019;32(4): 226-237.

9. T.C Sağlık Bakanlığı, Sağlık İstatistikleri Yılığı 2017. https://dosyasb.saglik.gov.tr/Eklenti/31096,turkcesiydijiv1pdf.pdf?0 Accessed Nov 112019.

10. Demircan A, Keleş A, Guerbuez N, Bildik F, Aygencel ŞG, Doğan NÖ, et al. Forensic emergency medicine-six-year experience of 13823 cases in a university emergency department. Turk J Med Sci. 2008;38(6): 567-5.

11. Sogut O, Sayhan MB, Gokdemir MT, Boleken ME, Al B, Kose R, et al. Analysis of hospital mortality and epidemiology in trauma patients: a multi-center study. J Curr Surg. 2011;1(1): 19-24.

12. World Health Organization. The world health report: 1999: making a difference. World Health Organization, 1999. https://www.who.int/whr/1999/en/whr99_en.pdf?ua=1 Accessed Nov 2019.

13. Akbaba M, Nazlican E, Demirhindi H, Sütoluk Z, Gökel Y. Etiological and demographical characteristics of acute adult poisoning in Adana, Turkey. Hum Exp Toxicol. 2007;26(5): 401-406.

14. Stomp W, Fidler V, ten Duis HJ, Nijsten MW. Relation of the weather and the lunar cycle with the incidence of trauma in the Groningen region over a 36-year period. J Trauma Acute Care Surg. 2009;67(5): 1103-1108.

15. Rotstein Z, Wilf-Miron R, Lavi B, Shahar A, Gabbay U, Noy S. The dynamics of patient visits to a public hospital ED: a statistical model. Am J Emerg Med. 1997;15(6): 596-599.

16. Korkmaz T, Kahramansoy N, Erkol Z, Saricil F, Kilci A. Evaluation of the forensic patients presenting to the emergency department and legal reports/Acil Servise Basvuran adli Olgularin ve Duzenlenen Adli Raporlarin Degerlendirilmesi. Med Bull Haseki. 2012;50(1): 14-21.

17. GBD 2017 Disease and Injury Incidence and Prevalence Collaborators. Global, regional, and national incidence, prevalence, and years lived with disability for 354 diseases and injuries for 195 countries and territories, 1990-2017: a systematic analysis for. for the Global Burden of Disease Study 2017. Lancet. 2018;392: 1789-858.

18. Prekker ME, Miner JR, Rockswold EG, Biros MH. The prevalence of injury of any type in an urban emergency department population. J Trauma Acute Care Surg. 2009;66(6): 1688-1695.

19. Turkish Statistical Enstitue. http://www.tuik.gov.tr/UstMenu.do?metod=temelist Accessed: 28 Jan 2020. 


\section{Acin et al.}

20. Turkish Statistical Enstitute. http://www.tuik.gov.tr/PreTablo.do?alt_id=1051 28 Jan 2020.

21. Aygencel G, Karamercan M, Ergin M, Telatar G. Review of traffic accident cases presenting to an adult emergency service in Turkey. J Forensic Leg Med. 2008;15(1): 1-6.

22. Puvanachandra P, Hoe C, Özkan T, Lajunen T. Burden of road traffic injuries in Turkey. Traffic Inj Prev. 2012;13(1): 64-75.

23. Özkan T, Lajunen T. Why are there sex differences in risky driving? The relationship between sex and gender-role on aggressive driving, traffic offences, and accident involvement among young Turkish drivers. Aggress Behav. 2005;31(6): 547-558.

24. Esiyok B, Korkusuz I, Canturk G, Alkan HA, Karaman AG, Hamit HI. Road traffic accidents and disability: A cross-section study from Turkey. Disabil Rehabil. 2005;27(21): 1333-1338.

25. World Health Organization. Falls. Jan 16, 2018. http://www.who.int/news-room/factsheets/detail/falls Accessed 7 May 2020.

26. World Health Organization, Global Status Report on Violence Prevention https://www.who.int/violence_injury_prevention/violence/status_report/2014/en/ Accessed 21 Dec 2019.

27. World Health Organization. Global status report on road safety 2018. World Health Organization, https://www.who.int/violence_injury_prevention/road_safety_status/2018/en/ Accessed 17 Dec 2019.

28. Gawryszewski VP, Silva MMAD, Malta DC, Kegler SR, Mercy JA, Mascarenhas MDM, et al. Violence-related injury in emergency departments in Brazil. Rev Panam Salud Publica. 2008;24: 400-408.

29. Özcan N, İkincioğulları D. Ulusal zehir danışma merkezi 2008 yılı çalışma raporu özeti. Turk Hij Tecr Biyol Derg. 2009;66(ER-3): 29-58.

30. Satar S, Seydaoglu G. Analysis of acute adult poisoning in a 6-year period and factors affecting the hospital stay. Adv Ther. 2005;22(2): 137-147.

31. Kahramansoy N, Erkol H, Kurt F, Gürbüz N, Bozgeyik M, Kıyan A. Analysis of trauma patients in a rural hospital in Turkey. Turk J Trauma Emerg Surg. 2011;17(3): 231-237. 